\title{
LISTENING, GRAMMAR, AND READING COMPREHENSION SKILLS OF THE TEST OF ENGLISH AS A FOREIGN LANGUAGE: A CORRELATIONAL STUDY
}

\author{
Jimmy Sapoetra \\ Primary Teacher Education Department, Faculty of Humanities, Bina Nusantara University \\ Jln. Kemanggisan Ilir III No. 45. Palmerah, DKI Jakarta 11480, Indonesia \\ jsapoetra@binus.edu
}

\begin{abstract}
The article aimed to investigate whether there was a correlation among the language skills and components. The researcher took two language skills and one language component to be part of the research: listening, reading comprehension skills, and grammar mastery. In the research, there were several questions regarding the three variables of listening, reading, and grammar which were focusing on the correlation among the variables. The independent variable was grammar mastery $(X)$ while the independent variables were listening comprehension (Y1) and reading comprehension (Y2). The data collection was taken from the population of Grade X Budi Luhur Senior High School students, Tangerang, with 40 students served as a sample. The research was conducted using the quantitative method with the help of statistical calculation of Pearson Product Moment Correlation to prove whether there was a significant correlation among the three variables. As a result, it is proven that there is no significant correlation between grammar mastery and both listening and reading skills while there is a quite strong correlation between listening and reading skills of the students.
\end{abstract}

Keywords: listening comprehension, reading comprehension, grammar mastery, correlational study

\section{INTRODUCTION}

English as an international language plays a vital role in almost all aspects of life. It is used not only as a means of communication but also as a medium of instruction in the classroom. There is a saying, "English is the gateway to the world" which means that without it, people cannot survive in the global society. There are several reasons why English has become an international language, namely; (1) migration by English speakers, (2) colonialism by the British, (3) the international role and influence of the USA commerce, international communications, media, films, and the spread of new technology (Crystal, 2009). Mastering English skills are essential since most people in the world use English as a means of communication, not only in the formal setting such as education but also in daily conversations. To be able to communicate well, one must have the certain ability in the four language skills (listening, speaking, reading, writing) that supported by the two language components (grammar and vocabulary).

This research is focusing on the correlation between the two language skills (listening and reading) and grammar mastery. The researcher wants to know whether there is the significant correlation between the two language skills (listening and reading) and one language component (grammar mastery). The research is also done to explore more varieties in the teaching-learning process. By knowing the strengths and weaknesses of the students, the researcher is able to create better learning activities to improve the language skills and components. 
In the context of education, on the one hand, the English language has a strategic position because almost all of the textbooks in various disciplines from elementary to college education are written in English. On the other hand, there is still a significant gap between the government regulation and the English mastery level among the students. Many students are still struggling, and they need to learn the language at courses or having the private teacher at home.

One of the most important aspects of university education for English as Foreign Language (EFL) students is a high level of proficiency in English to help them progress through their education. Proficiency can be defined as, "The ability of students to use the English language to make and communicate meaning in spoken and written contexts while completing their university studies" (Ghenghesh, 2015). English as a global language (Crystal, 2009) has a strategic position in the human life and globalization era, especially in making a meaningful and comprehensive relationship with other people or countries from all over the world. For the students, the mastery of English language would be a bridge to explore the world and the knowledge of human life. The strategic position of English in this globalization era has been a compulsory subject in the Indonesian national curriculum from primary to secondary levels. In Indonesia, it is established through the government regulation of the Republic of Indonesia number 19 of 2005 about the national education standards. Based on the regulation, the English language is recommended as a compulsory subject to be taught at primary to secondary levels in Indonesia.

In this study, the researcher analyzes "The Correlation among Listening, Grammar, and Reading Skills of the Test of English as a Foreign Language". There are three reasons why the researcher decided to choose the topic, which are; (1) an adequate English competency is essential especially among students in order to achieve a good career in their future, (2) one of the international standardized tests to measure one's English ability is the Test of English as a Foreign Language (TOEFL), and (3) in the TOEFL test (paper based), there are skills which must be learned in order to get a good score. The scores are somehow depending on how well the learners master certain skills (listening, grammar, and reading). Having those issues in mind, the researcher is interested in investigating whether there is the correlation between the English skills mentioned above. This means that whether a student who has good listening skill will also have a sound skill in reading and vice versa. Another element is the structure of the language. It is also important to know whether a student who has a good knowledge of structure will also have a good score in the other two skills (listening and reading).

The argument for testing English-language skills in all four domains is based on the following assertion that language is the primary (and unique) vehicle by which human beings communicate, that is, share ideas, express intentions, convey information, and so forth (Powers, 2013). Reading comprehension is a complex mental activity and is believed to be affected by many factors and their interplay. Among the different factors that influence reading comprehension, background knowledge - and content background knowledge in particular - has been extensively studied (Ou, 2012). Reading is a complex and long systematic direct instruction of multiple metacognitive lasting processes. In the process of reading, readers and writers interact through a text. That means readers extract meaning from the text and reconstruct it by combining information from text and their background knowledge (Hosseini, 2012).

By knowing whether there is the correlation between the English skills, the researcher considers several benefits for the language learners and educators. English learners will feel more confident in doing the TOEFL test as they know which specific skill they are weak or strong at. So they are able to achieve a better result by strengthening their weak skills and have more strategies in doing the TOEFL test since they are aware that having good listening skill will influence their reading score and vice versa. They will also be more motivated in doing the test because the result will depend not only on one skill but also other skills. English educators will have more knowledge and skills on 
how to help the students to improve their TOEFL score as they are able to analyze the students' strengths and weaknesses in the skills tested.

\section{METHODS}

The main purpose of this study is to investigate whether there is any correlation between listening, grammar, and the reading comprehension skills of the students at Budi Luhur Senior High School, Tangerang. As such, the independent variable is the grammar and the dependent variables are listening and reading comprehension skills. Since the study attempts to prove the correlation between the variables, the design type is correlation research. It can be seen in Figure 1.

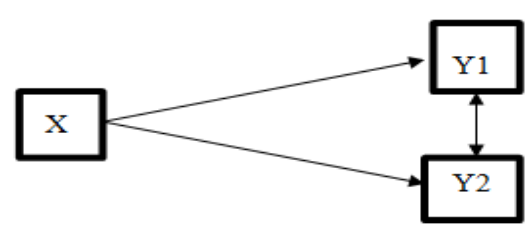

Figure 1 Constellation of the Problem

The assessment of the factors mentioned is carried out through three sets of instruments (listening, reading, and grammar test) taken from Longman Preparation Course for the TOEFL test (Philips, 2003). Through these instruments, the researcher intends to measure the level of the students' mastery in grammar, listening, and reading comprehension skills. Before doing the research analysis, the researcher has conducted the validity and reliability test of the instruments towards 20 students of $10^{\text {th }}$ grade at Budi Luhur Senior High School as the samples. Furthermore, the relationships between grammar mastery $(\mathrm{X})$ and listening comprehension skills (Y1), grammar mastery $(\mathrm{X})$ and reading comprehension skills (Y2), and listening comprehension (Y1) and reading comprehension (Y2) skills are partially assessed. Thus, basically this research is done to find out the relationships between grammar mastery $(\mathrm{X})$ with listening comprehension skills $(\mathrm{Y} 1)$, grammar mastery $(\mathrm{X})$ with the reading comprehension skills (Y2), listening comprehension (Y1) and reading comprehension (Y2) skills of the $10^{\text {th }}$ grade students at Budi Luhur Senior High School.

The research setting is at Budi Luhur Senior High School that located in Jalan Raden Saleh 999 - Karang Tengah, Tangerang. The subjects of this research are the students from the $10^{\text {th }}$ grade of Budi Luhur Senior High School, Tangerang which consisted of 20 students taken as the samples for the validity and reliability test. After that, another 20 students out of 108 students are selected randomly as the research samples. This study is based on the quantitative research method. Every researcher has different definitions of quantitative research. Fraenkel and Wallen (2008) have defined the quantitative research as, "The belief that facts and feelings can be separated, that the world is a single reality made up of facts that can be discovered." In this case, the quantitative research seeks to establish relationships between variables and look for and, sometimes, explain the causes of such relationships. Based on the above definition, the researcher has concluded that quantitative research is essentially about collecting numerical data to explain a particular phenomenon, the particular problem which is likely to be answered by using the quantitative methods.

According to Fraenkel and Wallen (2008), the quantitative research methodology has five types. They are (1) experimental research, (2) single-subject research, (3) correlational research, (4) causal-comparative research, and (5) survey research. Each type has its own unique characteristics. 
The researcher decides to use correlational design to be used in this study. The researcher uses coefficient correlation to analyze the data. Next, the researcher started to focus on the students' scores of grammar, listening, and reading comprehension. The researcher determines if there is any correlation between the students' achievements in the grammar, listening, and reading comprehension. The researcher uses the formula of Pearson Product Moment Correlation Coefficient to describe and find out the significance of the correlation between the three variables; variable X, Y1, and Y2. Variable $\mathrm{X}$ belongs to the independent variable, while variables $\mathrm{Y} 1$ and $\mathrm{Y} 2$ belong to the dependent ones.

The sampling technique used in this research is the simple random sampling, which is the sampling of random members of the population, by the assumption that all the students have the same opportunity to be members of the sample (Fraenkel and Wallen 2008). Eight steps of the sampling were done by compiling a list of students based on the data from Budi Luhur Senior High School. After that, the researcher printed out the names of all the students in the $10^{\text {th }}$ grade. There were 108 students divided into four classes. The researcher rolled the printed papers written with all of the students' names and put them into a box. After that, the researcher came to the four classes alternately and asked some students to draw lots randomly by using the rolled printed paper. The number of the paper rolls was adjusted to the number of the sample that has already been predetermined. After taking all paper rolls, the researcher, then, read the names of students who were selected randomly earlier. The mentioned students were thus defined as the research sample. With the help of the English teacher, the researcher then selected 40 students randomly from the four classes of the $10^{\text {th }}$ grade as the samples for the research instruments. After that, the researcher then did the random selection one more time for 20 students to be the test samples for the research instruments to participate in the test for the listening, reading, and grammar. The results of the test instrument were analyzed to determine the level of the instrument validity. The valid questions were used as the research instruments whereas the invalid ones were discarded. In addition, the instruments were also tested for their reliability. The reliable questions were used as the research instruments. The reliable and valid instruments were then tested to the 40 students who served as the research samples of this research. The tests were personally distributed by the researcher to the students of $10^{\text {th }}$ grade at Budi Luhur Senior High School. The data were collected over a period of one week. The next thing to do was to determine the right time to implement the test. Every class did the three tests items in two days because the tests needed 120 minutes to finish it, while the number of periods for English was only 90 minutes in one day. Every student got three sets of the printed test items; each student got one set for the listening comprehension, reading comprehension, and grammar.

The research instruments play an important role in collecting data. The instruments used in this research are the objective tests in the form of multiple-choices. In this research, the tests consist of three kinds, namely listening comprehension, reading comprehension, and grammar. Each kind of the tests is composed in 50 questions, except for the grammar that has 40 questions, in which every question comprises four alternatives of $\mathrm{a}, \mathrm{b}, \mathrm{c}$, or $\mathrm{d}$. The alternatives include one correct answer and three wrong answers.

In the listening comprehension part, there are 50 questions in multiple choices form. The listening comprehension questions comprise the main ideas, details, and inferences. In the reading comprehension part, there are five passages that completed with the comprehension questions. The reading comprehension questions comprise the main ideas, details, and inferences. Meanwhile, in the grammar part, there are 40 questions that are divided into two parts; the structure and the written expression. The structure has 15 questions while the written expression has 25 questions.

Before doing the analysis, the researcher did the some steps. First, the researcher conducted the validity and reliability test of the instruments towards 20 students of $10^{\text {th }}$ grade as the samples. Second, the researcher specified the type of instruments to be used in this research. The types of instruments chosen were the listening, reading comprehension, and grammar. Third, having 
established the types of the instruments to be used, the researcher, then, made the grids for the listening comprehension, reading comprehension, and grammar that would be tested.

After the three steps had been completed, the researcher made a trial test to the 20 students of $10^{\text {th }}$ grade. Before being used as the assessment instruments, the researcher firstly tested to the trial group from $10^{\text {th }}$ grade students to determine its validity and reliability. The reliable and valid questions were used for the measurement tools in the research, while the invalid and unreliable questions that were discarded and not going to be used in this research. In the process of examining the instrument validity and reliability, the researcher used a computer program; the SPSS version 16.00 for windows. The validity and reliability test of the instruments were conducted in August 2013, while the collection of the data samples was conducted in September 2013. The statistical data analysis and report writing were done in October and November 2013.

\section{RESULTS AND DISCUSSIONS}

From the data analysis and hypothesis testing, it comes out that there are three results that will be elaborated in this paragraph. First, there is no significant relationship between structure and the listening comprehension skills of the students at Budi Luhur Senior High School. This can be seen with a correlation coefficient of 0,180 which is classified as a relatively weak correlation and the determination coefficient is 0,032 , which means that $3,2 \%$ of the scores of the listening comprehension is affected by the mastery of structure. Second, there is no significant relationship between structure and reading comprehension skills of the students at Budi Luhur Senior High School. This can be indicated with a correlation coefficient of 0,257 which is classified as a relatively weak correlation with a determination coefficient of 0,066 , which means that $6,6 \%$ of the scores of the reading comprehension is influenced by the mastery of structure. Lastly, there is significant relationship between the listening comprehension and the reading comprehension skills of the students at Budi Luhur Senior High School. This is shown by the correlation coefficient of 0,519 which is classified as high. This relationship is relatively strong. The coefficient of determination is 0,269 , which means that $26,9 \%$ of the score of the listening comprehension is affected by the reading comprehension. The good level of the reading comprehension can contribute to the higher score of the listening comprehension. Based on the description of the data and the analysis of the data by using the normality test, linearity test, and the homogeneity test, it can be inferred from the results of the analysis of all the research data that hypothesis 3 is shown to have significant relationship between the two variables, namely the listening comprehension and the reading comprehension.

Table 1 Bivariate Correlations between (X) and (Y1) Correlations

\begin{tabular}{llrr}
\hline & & Listening & Structure \\
\hline Listening & Pearson Correlation & 1 & 0,180 \\
& Sig. (2-tailed) & & 0,267 \\
& $\mathrm{~N}$ & 40 & 40 \\
Structure & Pearson Correlation & 0,180 & 1 \\
& Sig. (2-tailed) & 0,267 & \\
& $\mathrm{~N}$ & 40 & 40 \\
\hline
\end{tabular}

**. Correlation is significant at the 0,01 level (2-tailed). 
Table 1 shows that the Pearson's Correlation score is 0,180. Meanwhile the significant probability score is 0,267 . The significant score is $0,267>0,05$, thus, it can be concluded that there is no significant relationship between the variables of structure $(\mathrm{X})$ and listening comprehension $(\mathrm{Y} 1)$. The Pearson's Correlation score is 0,180 , which shows that the relationship between the two variables is relatively weak, as they are not in the range of scores between 0,400 and 0,599. Figure 2 shows the scatter plot of structure (X) and listening (Y1).

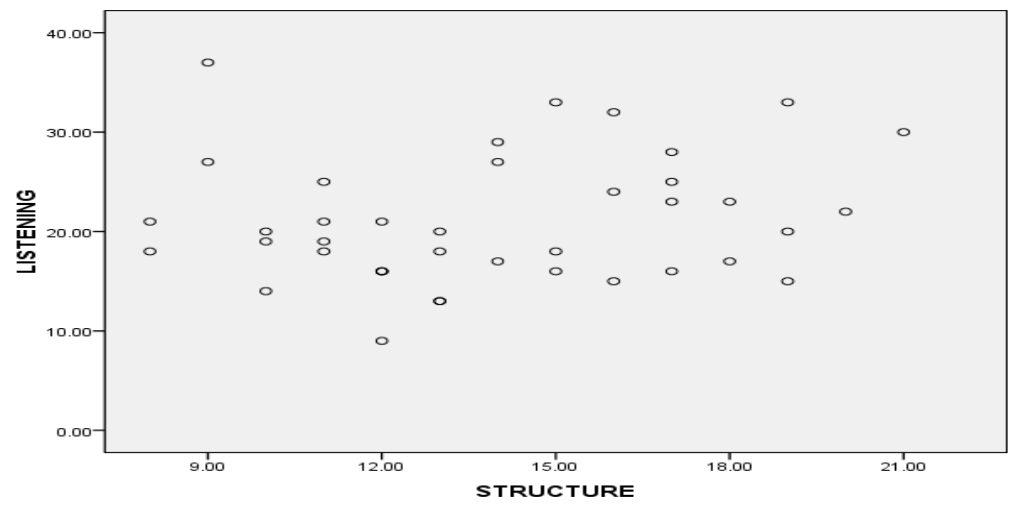

Figure 2 The Scatter Plot of Structure (X) and Listening (Y1)

Table 2 Bivariate Correlations between (X) and (Y2) Correlations

\begin{tabular}{llrr}
\hline & & Reading & Structure \\
\hline Reading & Pearson Correlation & 1 & 0,257 \\
& Sig. (2-tailed) & & 0,110 \\
& N & 40 & 40 \\
Structure & Pearson Correlation & 0,257 & 1 \\
& Sig. (2-tailed) & 0,110 & \\
& N & 40 & 40 \\
\hline
\end{tabular}

From Table 2, it is identified that the correlation coefficient is 0,257 . The score of Pearson's Correlation is 0,257 showing that the relationship of the two variables is weak because the range of scores is not between 0,400 and 0,599. Figure 3 shows the scatter plot of structure $(X)$ and listening $(\mathrm{Y} 2)$.

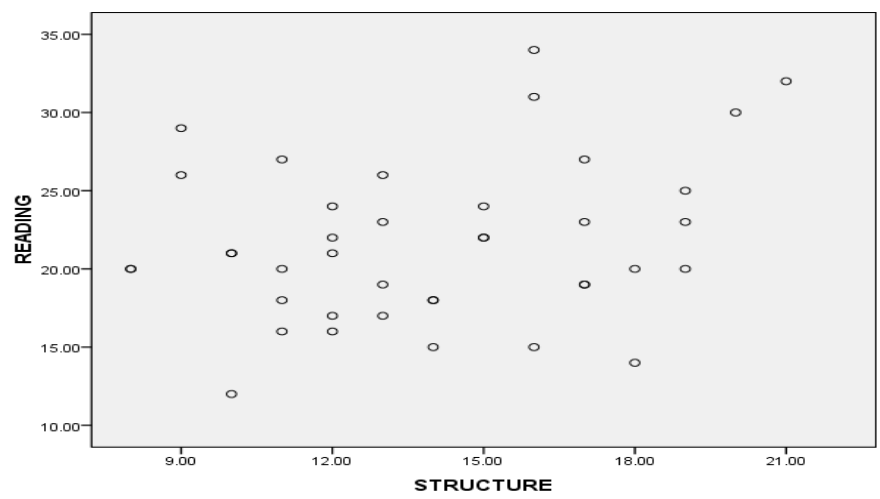

Figure 3 The Scatter Plot of Structure (X) and Reading (Y2) 
Table 3 Bivariate Correlations between (Y1) and (Y2) Correlations

\begin{tabular}{rlrr}
\hline & & Listening & \multicolumn{1}{c}{ Reading } \\
\hline Listening & Pearson Correlation & 1 & $0,519^{* * *}$ \\
& Sig. (2-tailed) & & 0,001 \\
& $\mathrm{~N}$ & & 40 \\
\multirow{4}{*}{ Reading } & Pearson Correlation & $0,519^{* *}$ & 1 \\
& Sig. (2-tailed) & 0,001 & \\
& $\mathrm{~N}$ & 40 & 40 \\
\hline
\end{tabular}

**. Correlation is significant at the 0,01 level (2-tailed).

Based on Table 3, it can be described that the relationship between the listening and the reading comprehension shows a significant correlation. This relationship is quite strong because it is in the range of 0,400 to 0,599 . Figure 4 shows the scatter plot of structure (Y1) and listening (Y2).

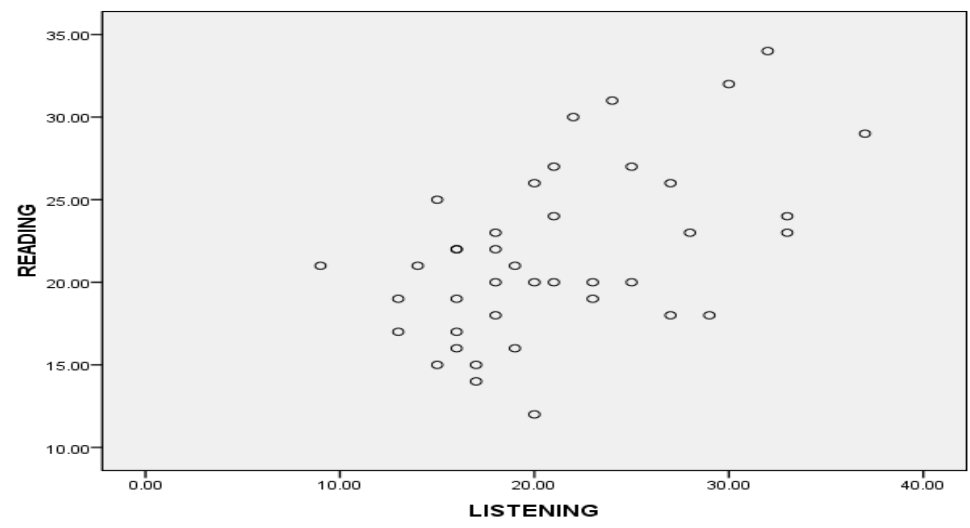

Figure 4 The Scatter Plot of Listening (Y1) and Reading (Y2)

According to Mecartty (2000) there should be a significant contribution of the grammatical knowledge to the listening comprehension ability. One who has adequate language structure should also be aware of using it in the listening task. However, it is also pointed out that there has not been enough study to really prove the theory. In this case, based on the study of the correlation between the two variables of structure and the listening comprehension, the researcher concludes that there is no significant correlation between the two variables. It means that good knowledge of language structure does not guarantee the sound skill of listening comprehension or vice versa.

In regards with the relationship between structure and reading comprehension, Grabe (2002) has stated that fluent readers need a sound knowledge of language structure and vocabulary. There are several agreement and disagreement on the view since many other factors have to be considered, such as the types of questions in the tests, level of test difficulties, and many more. However, based on the study, the researcher finds out that there is no significant correlation between the two variables of structure and reading comprehension. In other words, a good grammatical knowledge does not directly affect the reading comprehension skill.

Spring \& French (1990) has stated that listening and reading are both receptive language skills. In both listening and reading, but the primary objective is to develop meaning. Listening comprehension develops prior to reading comprehension but the relationship between listening and 
reading becomes more complex as development progresses. In this study, the researcher investigated that there was significant correlation between listening and reading comprehension skills. This means that a good reading comprehension skill would certainly affect the listening comprehension skill and vice versa.

\section{CONCLUSIONS}

Based on the problem formulation, it can be concluded that there is no significant relationship between the variables of structure and the listening comprehension skills of the students at Budi Luhur Senior High School. This could be seen with a correlation coefficient of 0,180 which is classified as a weak relationship and the determination coefficient of 0,032 , which means that only $3,2 \%$ of the score in listening comprehension is affected by the structure. Then, there is no significant relationship between structure and the reading comprehension skills of the students at Budi Luhur Senior High School. This can be seen with the correlation coefficient of 0,257 which is classified as a weak relationship and the determination coefficient of 0,066 , which means that only $6,6 \%$ of the score in the reading comprehension is affected by the structure. And there is a significant correlation between the listening comprehension and the reading comprehension skills of the students at Budi Luhur Senior High School. This is shown by the high correlation coefficient of 0,519 . This relationship is quite strong. The coefficient determination is 0,269 , which means that $26,9 \%$ of the score of the listening comprehension is affected by the reading comprehension. The more students master the reading comprehension, the better their listening comprehension will be.

It could be done through the following practices; (1) the teachers need to design fun activities that focusing on improving the students' skills in listening through games which are available freely online. (2) The teachers can guide the students to make up as many words exposure as possible. The teachers can ask the students to say the words loudly to activate their auditory memory. In addition, they should be guided to relate the words to the words they have already known. (3) The teachers may use listening tests. For more serious learning, there are many books that focus on listening skills most commonly found in standardized tests, such as TOEFL and IELTS. There are also many interesting sites on the Internet that the students can visit. (4) The teachers can lead the students to take online listening tests that are provided freely on the Internet. Those online listening tests will help the students to increase their listening skills and let them know how much they have made progress in their learning.

In addition to improving students' listening skills, pedagogical implications can also be advantageous in obtaining the reading comprehension skills of the students at Budi Luhur Senior High School if teachers practice the following suggestions; (1) the teachers should encourage the students to read more. Thus, the students should learn the new words comprehensively in order to enhance the reading comprehension skills. (2) The teachers should facilitate the students in learning the new vocabularies continuously in the teaching and learning processes either in the classroom, outside the classroom or online learning. (3) The teachers should be aware in providing a conducive and meaningful learning atmosphere in the classroom so that it can help the students learn new words independently at home or anywhere they can. (4) A variety of methods of teaching reading to the students in the classroom would be an advantage to make the teaching atmosphere in the classroom more interesting and meaningful for the students. It can be done by playing games or doing quizzes.

Beside the teachers, students can obtain the benefits of the pedagogical implications as well. One of the benefits is to improve the listening skills. The students of Budi Luhur Senior High School can follow these following practices; (1) the students can listen to many kinds of songs, news, stories, and try to understand what they have listened to. (2) The students can also improve their listening 
skills by listening to the English radio and watching television or films. (3) The students may use listening tests. For more serious learning, there are many books that are providing listening exercises or tests in which the students can use. (4) The students can take online listening tests or they can do English quizzes which are provided freely on the Internet. Those online listening tests and quizzes will help the students to practice and get more exposures.

Moreover, in order to enhance the reading comprehension skills, the students of Budi Luhur Senior High School can practice the following ways; (1) the students should have a meaningful reading time regularly. This can be done at school or home depends on the time availability. (2) The students must get as many exposures as they can so that they become skillful in the reading materials including scientific or non-scientific texts. (3) The students are advised to write a journal that tell what they read so it will be more interested and motivated to read more. (4) Make reading activity as a habit. Reading will be fun if it is done with enjoyment.

Finally, the institutions can also obtain the advantage of pedagogical implications in developing the skills of the teachers especially in the development of the teaching and learning process. Here are some suggestions that may be used by the institutions to improve the performance of the teachers; (1) it is advisable to give more seminars, trainings, and workshops to the teachers especially in developing the methods and approaches in teaching English. (2) The institution can facilitate teachers with the supporting teaching aids, such as games and different kinds of computer software. (3) The institution needs to emphasize the teachers that learning must take place at anytime and anywhere. The focus of the learning is the students. The teachers only facilitate and support the students when needed. (4) It is always good for any institution to learn from other partners. Partnership is a good way in strengthening the school performance. There are always something new to learn during school gathering or meetings. Joining a reputable international organization would also be beneficial for the school.

\section{REFERENCES}

Crystal, D. (2009). English as a Global Language. Cambridge: Cambridge University Press. doi: https://doi.org/10.1017/CBO9780511486999.

Fraenkel, J. R., \& Wallen, N. E. (2008). How to Design and Evaluate Research in Education. New York: McGraw-Hill Companies, Inc.

Grabe, W., \& Stoller, F. L. (2002). Teaching and Researching Reading. London: Pearson Education Longman.

Ghenghesh, P. (2015). The Relationship Between English Language Proficiency And Academic Performance of University Students - Should Academic Institutions Really be Concerned? International Journal of Applied Linguistics and English Literatur, 4(2), 91-97.

Hosseini, E. (2012). Exploring the Relationship Between Critical Thinking, Reading Comprehension and Reading Strategies of English University Students. World Applied Sciences Journal, 17(10), 1356-1364.

Mecartty, F. H. (2000). Lexical and Grammatical Knowledge in Reading and Listening Comprehension by Foreign Language Learners of Spanish. Applied Language Learning, 11(2), 323-348. 
Ou, L. L. (2012). Is There Any Interaction Between Background Knowledge and Language Proficiency That Affects TOEFL iBT® Reading Performance? New Jersey: Education Testing Service.

Phillips, D. (2003). Longman Preparation Course for the TOEFL Test. New York: Pearson Education, Inc.

Powers, E. D. (2013). Assessing English Language Proficiency in All Four Language Domains: Is it Really Necessary? New Jersey: Education Testing Service.

Republik Indonesia. (2005). Undang-Undang Tahun No. 19 tentang Standar Pendidikan Nasional. Lembaran Negara Republik Indonesia Tahun 2005 Nomor 41. Kementerian Hukum dan Hak Azasi Manusia. Jakarta.

Spring, C., \& French, L. (1990). Identifying Children with Specific Reading Disabilities from Listening and Reading Discrepancy Scores. Journal of Learning Disabilities. 23(1), 53-8. 